\title{
KAJIAN BIOMASA TEGAKAN ATAS PERMUKAAN (ABOVEGROUND BIOMASS) DAN CADANGAN KARBON DI BEBERAPA TAMAN KOTA PONTIANAK
}

\author{
Andi Maryadi ${ }^{1}$, Rafdinal $^{1}$, Riza Linda $^{1}$ \\ ${ }^{1}$ Program Studi Biologi, Fakultas MIPA, Universitas Tanjungpura, \\ Jl. Prof. Dr. H. HadariNawawi, Pontianak, 78124 \\ email korespondensi: andimaryadi327@gmail.com
}

\begin{abstract}
Pontianak as the a city the of West Kalimantan, of course, encountered the descrease of land from year to year. This issue leads to the increase of carbon emission in the air. The aim of this research is to find out how much biomass and reserved carbon on the surface of gardens in the Pontianak city. This study was conducted from March to June 2017. This used non-destructive methods and alometric equations, data collection was gathered through census on each stand up by measuring $\mathrm{DBH} \geq 5 \mathrm{~cm}$. The results of this study shows that biomass above the oil surface at five gardens in Pontianak city was around 36,85-473,42 ton/Ha and reserves carbon was around 18,42-236,71 ton $\mathrm{C} / \mathrm{Ha}$. The highest reserve carbon was on street of Jalan Ahmad Yani 1 with the value of reserved carbon was around 236.71 ton $\mathrm{C} / \mathrm{Ha}$ and the lowest reserved carbon was at the garden of Tugu Khatulistiwa, that was 18.42 ton $\mathrm{C} / \mathrm{Ha}$.
\end{abstract}

Keywords : Biomasa, Reserved Carbon, Pontianak City Gardens

\section{PENDAHULUAN}

Perubahan iklim akibat pemanasan global serta emisi Gas Rumah Kaca (GRK) merupakan salah satu isu yang sedang berlansung pada saat ini. Emisi gas rumah kaca (GRK) akan menyebabkan terjadinya kenaikan suhu permukaan bumi. Kementrian Lingkungan Hidup dan Kehutanan (2015) menyatakan bahwa emisi GRK dari sektor energi pada tahun 2013 mencapai $548.355 \mathrm{Gg} \mathrm{CO}_{2}$ sekitar $96.19 \%$ berasal dari pembakaran bahan bakar dan sisanya berasal dari emisi fugitive. Ini menunjukkan bahwa daerah perkotaan yang berperan aktif dalam meningkatnya jumlah emis $\mathrm{CO}_{2}$ di udara. Meningkatnya suhu udara di perkotaan menyebabkan keberadaan taman kota dan ruang terbuka hijau sangat penting keberadaanya di daerah perkotaan.

Taman kota merupakan salah satu bagian dari ruang terbuka hijau (RTH) kota. Menurut Purnomohadi (1995) dalam Direktorat Jenderal Penataan Ruang (2006), pengertian RTH adalah sebentang lahan terbuka tanpa bangunan yang mempunyai ukuran, bentuk, dan batas geografis tertentu dengan status penguasaan apapun, yang di dalamnya terdapat tumbuhan hijau berkayu dan tahunan (perennial woody plants), dengan pepohonan sebagai tumbuhan ciri utama dan tumbuhan lainnya (perdu, semak, rerumputan, dan tumbuhan penutup tanah lainnya) sebagai tumbuhan pelengkap, serta benda-benda lain yang juga sebagai pelengkap dan penunjang fungsi Ruang Terbuka Hijau (RTH). Taman kota menjadi salah satu upaya dalam menjaga kestabilitasan iklim mikro perkotaan serta menjaga keseimbangan lingkungan didaerah perkotaan. Selain itu, pohon yang terdapat pada taman kota memiliki nilai fungsi dalam penyimpanan karbon yang terakumulasi dalam jumlah biomassa pada pohon tersebut.

Biomassa adalah total jumlah materi hidup di atas permukaan pada suatu pohon dan dinyatakan dengan satuan ton berat kering per satuan luas (Brown, 1997). Biomassa memiliki kaitan dengan cadangan karbon yaitu dengan mengukur jumlah cadangan karbon pada suatu lahan dapat menggambarkan jumlah $\mathrm{CO}_{2}$ di atmosfer yang terserap oleh pohon (Rahayu et al., 2007). Menurut hasil penelitian terdahulu yang dilakukan oleh Adhitya et al. (2013). Hutan kota yang berada di Ketapang memiliki rata - rata kandungan karbon sebesar 70,71 ton $\mathrm{C} / \mathrm{Ha}$. Hutan kota pada tingkat pohon mampu melakukan serapan (sequestration) terhadap karbon khususnya pada karbon bagian atas pemukaan tanah bagian batang, cabang, dan daun sebesar 18.202,91 tonC/Ha, dengan penyerapan $\mathrm{CO}_{2}$ rata-rata per hektarnya sebesar 207,76 ton $\mathrm{C} / \mathrm{Ha}$. Penelitian lain yang dilakukan 
oleh Azham, (2015) di tiga lokasi yang berbeda yaitu hutan sekunder, semak, dan belukar menyatakan bahwa hutan sekunder memiliki estimasi cadangan biomassa terbesar yaitu 203,826 ton $\mathrm{C} / \mathrm{ha}$, dan cadangan karbon di atas permukaan (aboveground karbon) sebesar 69,93 ton C/ha. Kota Pontianak sebagai kota yang merupakan pusat pemerintah daerah Kalimantan Barat terjadi pengurangan lahan dari tahun ke tahun akan semakin berkurang menurut analisis badan perencanaan pembangunan daerah (BAPPEDA) (2004) lahan pemukiman di Kota Pontianak mengalami peningkatan dari tahun 1994 sampai 2003 sebesar 6,56 \%. Upaya dalam menciptakan lingkungan yang bersih, maka dengan menanam pepohonan di daerah perkotaan dalam bentuk ruang terbuka hijau atau taman-taman kota sebanyak mungkin supaya menekan jumlah serapan $\mathrm{CO}_{2}$ dan mengurangi pelepasan emisi $\mathrm{CO}_{2}$ di udara hususnya di daerah perkotaan. Mengetahui jumlah biomassa tegakan atas permukaan above ground biomass dan cadangan karbon di taman Kota Pontianak merupakan hal yang penting untuk diketahui agar diketahui nilai serapan $\mathrm{CO}_{2}$ dan emisi karbon di udara yang diserap oleh beberapa taman Kota Pontianak sebagai upaya meminimalisir jumlah emisi karbon di udara.

Tujuan penelitian ini adalah untuk mengetahui berapa besaran potensi biomassa tegakan atas permukaan yang terdapat di beberapa Taman kota di Kota Pontianak dan untuk mengetahui berapa besaran potensi cadangan karbon tegakan atas permukaan di beberapa Taman Kota Pontianak.

\section{BAHAN DAN METODE}

\section{Waktu dan Tempat}

Penelitian ini dilaksanakan pada bulan Maret sampai April 2017. Pengambilan sempel dilaksanakan di lima taman kota yang ada di kota Pontianak Provinsi Kalimantan barat yaitu Jalur hijau sepanjang jalan Ahmad Yani 1, Jalan MT Haryono, taman Digulis Universitas Tanjungpura, Hutan depan Pendopo Gubernur dan taman yang dikelolah pihak swasta yaitu taman tugu khatulistiwa.

\section{Deskripsi Lokasi}

Kota Pontianak merupakan salah satu Kota di Indonesia yang dilintasi garis khatulistiwa. Kota Pontianak memiliki luas daerah 107,82 $\mathrm{km}^{2}$ menjadikan Kota Pontianak sebagai tempat tujuan wisata, baik domestik maupun manca negara. Peta penelitian dapat dilihat pada Gambar 1.

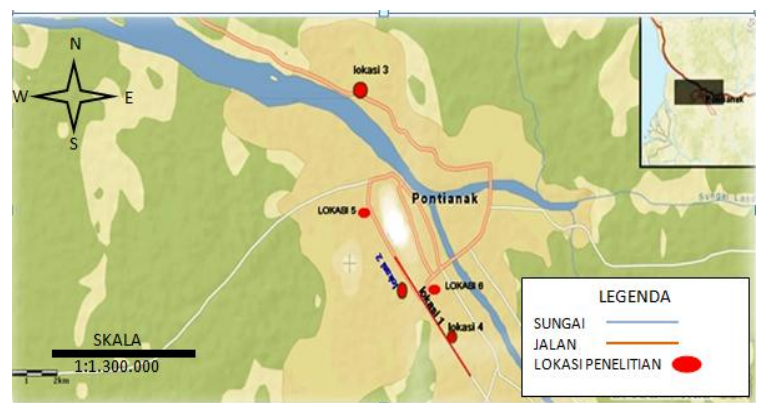

Gambar 1. Peta Lokasi Penelitian

\section{Alat dan Bahan}

Alat yang digunakan dalam penelitian ini adalah alat tulis, buku kerja lapangan, haga meter, daftar isian survei, Global Positioning System (GPS), gunting, kalkulator, kamera digital, kompas, meteran jahit, pita pengukur, tally sheet, tongkat kayu setinggi 1,3 meter.

Bahan yang digunakan dalam penelitian ini adalah biomassa tegakan bagian atas permukaan pohon hidup yang diambil dari pohon-pohon dengan mengukur Diameter Breast High (DBH) setinggi 1,3 $\mathrm{m}$ dari permukaan tanah di lokasi penelitian.

\section{Penentuan Lokasi}

Metode yang digunakan dalam penentuan lokasi sampling penelitian adalah metode purposive sampling (Fachrul, 2006). Pengambilan sampel dilakukan di lima Taman Kota Pontianak yaitu:

a. Taman yang terdapat di kiri kanan sepanjang jalan Ahmad Yani 1 (lokasi 1)

b. Taman yang terdapat di kiri-kanan Jalan MT Haryono (lokasi 2)

c. Taman yang dikelola Pihak swasta di Tugu Khatulistiwa (lokasi 3)

d. TamanDigulis Universitas Tanjungpura (lokasi 4)

e. Hutan depan Pendopo Gubernur

\section{Pendugaan Aboveground Biomass}

Pengamatan aboveground biomass Taman dilakukan dengan metode non-destruktif (tanpa pemanenan). Pengambilan data dilakukan dengan sensus tiap tegakan dengan $\mathrm{DBH} \geq 5 \mathrm{~cm}$. Data yang diambil meliputi diameter, jenis pohon dan jumlah individu. Data yang didapat kemudian menggunakan persamaan allometrik untuk menghitung jumlah biomassa dan cadangan karbon tersimpan (Hairiah et al., 2011). Persamaan alometrik sebagian pohon yang biasa terdapat di Taman dapat dilihat pada Tabel 1 . 
Tabel 1.Persamaan allometrik sebagian pohon

\begin{tabular}{lll}
\hline Jenis pohon/Tree species & Persamaan allometrik/Allometic equation & \multicolumn{1}{c}{ Sumber/Source } \\
\hline Mahoni & $\mathrm{Y}=0.048 \mathrm{D}^{2,68}$ & Hairiah et al., (2011) \\
Sengon & $\mathrm{Y}=0.027 \mathrm{D} 2.23$ & Hairiah et al., $(2011)$ \\
Akasia & $\mathrm{Y}=0.0000478 \mathrm{D}^{2.76}$ & Hairiah et al., $(2011)$ \\
Kelapa sawit & $(\mathrm{AGB}) \operatorname{est}=0.0976 \mathrm{H}+0.0706$ & Icraf, 2009 \\
Palam & $(\mathrm{AGB}) \operatorname{est}=\exp \{-2.134+2.530 \times \ln (\mathrm{D})\}$ & Brown, 1997 \\
Penang & $\mathrm{Y}=0,0219 *\left(\mathrm{D}^{2} \mathrm{x} \mathrm{D}\right)^{1,0102}$ & Kashengky, 2012 \\
Pohon lin-lain & $\mathrm{Y}=0,11 \rho \mathrm{DBH} \mathrm{H}^{2.62}$ & Kettering, et.al $(2001)$ \\
\hline
\end{tabular}

Keterangan: $\mathrm{Y}=$ Biomassa pohon (kg per pohon) $\mathrm{D}=\mathrm{DBH}(\mathrm{m}) \mathrm{H}=$ Tinggi pohon $(\mathrm{m})$

Persamaan alometrik berdasarkan spesies tidak tersedia, menggunakan Persamaan alometrik berdasarkan curah hujan yang dikembangkan oleh (Kettering et al., 2001) adalah sebagai berikut: Pendugaan biomassa dengan persamaan Kettering et.al., (2001)

$$
\begin{aligned}
\mathrm{Y} & =0,11 \rho \mathrm{DBH}^{2.62} \\
\text { Keterangan: } & =\text { biomassa total }(\mathrm{kg}) \\
\mathrm{DBH} & =\text { diameter setinggi dada }(\mathrm{m}) \\
\rho \quad & =\text { berat jenis kayu }(\mathrm{gr} / \mathrm{cm})
\end{aligned}
$$

Penentuan massa jenis kayu masing-masing jenis pohon berdasarkan pada Global Wood Density Database (2012).

Pengukuran DBH dan tinggi pohon biomassa pohon dengan cara sebagai berikut:

1. Mengukur diameter batang setinggi dada (DBH) diameter at breast height yaitu $1.3 \mathrm{~m}$ dari permukaan tanah) semua pohon

2. Melilitkan pita pengukur pada batang pohon, dengan posisi pita harus sejajar untuk semua arah.

3. Mencatat keliling batang atau diameter batang dari setiap pohon yang diamati pada format pengamatan yang telah disiapkan.

4. Mengukur semua diameter semua cabang khusus untuk pohon-pohon yang batangnya rendah dan bercabang banyak Di lapangan kadang-kadang dijumpai beberapa penyimpangan kondisi percabangan pohon atau permukaan batang pohon yang bergelombang atau adanya banir pohon, maka carapenentuan DBH dapat dilakukan seperti pada Gambar 2.

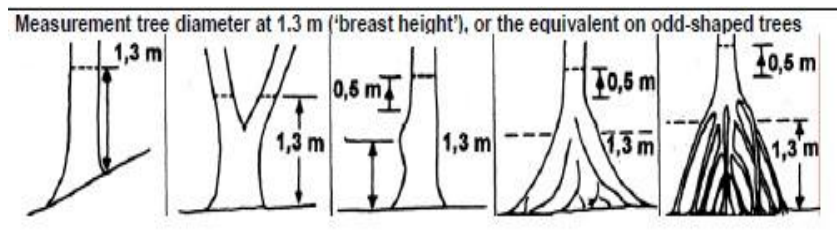

Gambar 2. Skematis cara menentukan ketinggian Pengukuran DBH Batang Pohon yang Tidak Beraturan Bentuknya (Sumber gambar: Hairiah dan Rahayu 2007)
Keterangan:

a. Pohon pada tanah berlereng, pengukuran diameter pohon dilakukan $1,3 \mathrm{~m}$ pada lereng bagian atas.

b. Pohon bercabang pengukuran diameter pohon dilakukan sebelum ketinggian 1,3 m dan semua cabang yang ada diukur.

c. Bila pada ketinggian $1,3 \mathrm{~m}$ terdapat benjolan, makan pengukuran diameter dilakukan pada 0,5 $\mathrm{m}$ setelah benjolan.

d. Bila pada ketinggian 1,3 m terdapat banir (batas akar papan), maka pengukuran diameter dilakukan pada $0,5 \mathrm{~m}$ setelah banir. Namun bila banir tersebut mencapai ketinggian $>3 \mathrm{~m}$, maka diameter batang di estimasi.

e. Bila pada ketinggian 1,3 m terdapat akar-akar tunjang, maka pengukuran diameter dilakukan pada $0,5 \mathrm{~m}$ setelah perakaran.

\section{Pengamatan Potensi Cadangan Karbon}

Analisis cadangan karbon pohon hutan Kota menggunakan pendekatan kandungan biomassa yang dikembangkan oleh Intergovernmental Panel on Climate Change (IPCC) (2006). Formulasi umum yang digunakan adalah:

$$
\mathrm{C}=0.5 \times \mathrm{W}
$$

\section{Keterangan: $\quad \mathrm{C}$ : Cadangan Karbon $(\mathrm{C})$ \\ $\mathrm{W}$ : Biomassa $(\mathrm{kg})$ \\ 0.5 : Koefisien kadar karbon pada tumbuhan}

\section{HASIL DAN PEMBAHASAN}

\section{Hasil}

\section{Jenis-jenis Pohon Dari Lima Lokasi Taman Kota Pontianak}

Berdasarkan hasil penelitian dari lima lokasi Taman Kota Pontianak tercatat ada 34 jenis pohon terbagi dalam 20 famili. Pohon yang paling banyak ditemukan di lima Taman Kota Pontianak yaitu pohon Swietenia mahagoni dengan jumlah 680 individu, Mimusops Elengai (Tanjung) dengan jumlah 413 individu, Pterocarpus indicus 
(Angsana) dengan jumlah individu ditemukan 247 individu kemudain pohon Alstonia scholaris (Pulai) dengan jumlah individu ditemukan 303 dan pohon Acacia Mangium (akasia) dengan jumlah individu ditemukan 135. Jenis-jenis pohon pada setiap lokasi di lima taman Kota Pontianak tersaji dalam Tabel 2.

Tabel 2 Jenis-Jenis pohon dari lima lokasi Taman Kota Pontianak

\begin{tabular}{|c|c|c|c|c|c|c|c|c|}
\hline \multirow{2}{*}{ No } & \multirow{2}{*}{ Famili } & \multirow{2}{*}{ Nama Spesies } & \multirow{2}{*}{ Nama lokal } & \multicolumn{5}{|c|}{ Jumlah Individu } \\
\hline & & & & 1 & 2 & 3 & 4 & 5 \\
\hline \multirow[t]{3}{*}{1} & Arecaceae & Roystonea regia & Palem rajah & - & 44 & 75 & 130 & 7 \\
\hline & & Elaeis guineensis jack & Kelapa sawit & 9 & - & 31 & - & - \\
\hline & & Cyrtostachys renda & Penang merah & - & - & - & 2 & - \\
\hline 2 & Annonaceae & Polyalthia longifolia & Glodogan & - & 30 & 59 & 1 & - \\
\hline \multirow[t]{2}{*}{3} & Anacardiaceae & Boueamarcophylla & Kendarah & - & - & - & - & 2 \\
\hline & & Anacardiumoccidentale & Jambu mete & & - & - & 16 & - \\
\hline \multirow[t]{2}{*}{4} & Apocynacea & Alstoniascholaris & Pulai & - & - & - & - & 303 \\
\hline & & Plunieria alba & Kamboja & - & - & - & - & + \\
\hline 5 & Bignoniaceae & Tabebuia & Tebubaya & - & - & 11 & - & - \\
\hline \multirow[t]{2}{*}{6} & Combretaceae & Terminalia Catappa & Ketapang & - & 1 & 8 & - & 9 \\
\hline & & Terminaliamantaly & Ketapang kencana & - & 2 & 27 & - & - \\
\hline 7 & Clusiaceae & Garcinia mangostana & Manggis & - & - & - & - & 12 \\
\hline 8 & Delliniaceae & Dilleniaaurea & Daun sempur & 2 & - & - & - & - \\
\hline \multirow[t]{4}{*}{10} & Fabaceae & Acacia Mangium & Akasia & 135 & - & 47 & - & 28 \\
\hline & & Samanea saman & Trembesi & - & 23 & - & 65 & - \\
\hline & & Erythrinavariegate & Dadap merah & - & 2 & - & - & - \\
\hline & & Albiziachinensis & Sengon & - & - & - & - & 42 \\
\hline 11 & Gnetaceae & Gnetumgnemon & Melinjo & - & 4 & - & - & - \\
\hline 12 & Lythraceae & $\begin{array}{l}\text { Lagerstroemia } \\
\text { speciosa }\end{array}$ & Bungor & - & - & - & - & 20 \\
\hline 13 & Lamiaceae & Tectonagrandis & Jati & - & - & - & - & 2 \\
\hline \multirow[t]{5}{*}{14} & Myrtaceae & Syzygiumoleana & Pucuk merah & 17 & 3 & 2 & - & - \\
\hline & & Melaleuca leucadendra & Kayu putih & - & - & - & 19 & - \\
\hline & & Syzygiummalaccense & Jambu bol & 1 & - & - & - & 1 \\
\hline & & Syzygumzeylaniium & Buah nasi-nasi & 53 & - & - & - & - \\
\hline & & $\begin{array}{l}\text { Eucalyptus } \\
\text { degluptablume }\end{array}$ & Pelangi & 5 & - & - & - & - \\
\hline \multirow[t]{2}{*}{15} & Meliaceae & Swieteniamahagoni & Mahoni & - & - & 680 & 69 & 25 \\
\hline & & Anglaiatomentosa & Langsat hutan & - & - & - & - & 1 \\
\hline \multirow[t]{2}{*}{16} & Malvaceae & Hibiscus tiliaceus & Waru & 28 & - & - & - & - \\
\hline & & Duriozibethinus & Durian & & - & - & - & 1 \\
\hline 17 & Moraceae & Artocarpus integer & Cempedak & 2 & - & - & - & - \\
\hline 18 & Papilionaceae & Pterocarpusindicus & Angsana & 7 & - & 247 & 11 & 10 \\
\hline 19 & Sapotaceae & Mimusops Elengi & Tanjung & 0 & 2 & 413 & 3 & 4 \\
\hline 20 & Sapindaceae & Filiciumdecipiens & Kiara payung & - & 1 & - & - & - \\
\hline \multicolumn{4}{|c|}{ Jumlah total individu pohon } & 259 & 112 & 1600 & 318 & 467 \\
\hline
\end{tabular}

Keterangan: (-) tidak ditemukan

Lokasa 1 Digulis Untan, Lokasi 2 Tugu Khatulistiwa, Lokasi 3 Jalan Ahmad Yani 1, lokasi 4 Jalan MT Haryono dan Lokasi 5 Hutan Pendopo Gubernur Kalimantan Barat

Berdasarkan dari lima lokasi Taman Kota Pontianak yang banyak ditemukan jumlah individu pohon adalah lokasi kiri-kanan Jalan Ahmad Yani 1 dengan jumlah total 1600 individu dan memiliki
11 jenis pohon kemudian pada lokasi Hutan Pendopo Gubernur dengan jumlah 467 indvidu pohon terbagi dalam 16 jenis pohon. 


\section{Biomassa Tersimpan di lima Taman Kota Pontianak}

Berdasarkan hasil pengamatan yang dilakukan di lima taman Kota Pontianak dengan mengukur diameter pohon setinggi dada dan perhitungan dengan persamaan alometrik berjumlah total biomassa 927,71 ton/Ha dengan berkisaran antara 36,85-473,42 ton/Ha. Nilai biomassa per taman dan jumlah individu pohon per taman dapat dilihat pada tabel 3 .

Tabel 3. Jumlah Biomassa di lima Taman Kota Pontianak

\begin{tabular}{cccc}
\hline Lokasi & $\begin{array}{c}\text { Luas } \\
(\mathrm{Ha})\end{array}$ & $\begin{array}{c}\text { Jumlah Individu } \\
\text { pohon }\end{array}$ & $\begin{array}{c}\text { Jumlah Biomassa } \\
\text { (ton C/Ha }\end{array}$ \\
\hline Taman digulis & 3 & 259 & 42,32 \\
Taman Tugu Khatulistiwa & 0,0953 & 112 & 36,85 \\
Jl. Ahmad Yani & 1,3151 & 1600 & 473,42 \\
Jl. MT. Haryono & 0,32 & 318 & 224,23 \\
Hutan Pendopo Gubennur & 2,3 & 467 & 150,89 \\
\hline Jumlah Total Biomassa & & 2756 & 927,71 \\
\hline
\end{tabular}

Berdasarkan Tabel 3 menunjukkan bahwa lokasi yang paling tinggi jumlah biomassa yaitu lokasi Jalan Ahmad Yani dengan jumlah biomassanya 473,42 ton/Ha. Hal ini dikarenakan jumlah individu pohon dilokasi tersebut memiliki jumlah individu yang lebih banyak dari pada lokasi yang lainnya tercatat di Jalan Ahmad Yani 1 memiliki jumlah individu pohon 1.600 individu. Kemudian lokasi yang terendah jumlah biomassa yaitu lokasi Taman Tugu Khatulistiwa dengan jumlah 36,85 ton/Ha. Hal ini dikarenakan jumlah individu pohon di lokasi tersebut memiliki jumlah pohon yang sedikit dengan jumlah 112 individu pohon sehingga mempengaruhi jumlah biomassa yang tersimpan

\section{Karbon Tersimpan di lima taman kota Pontianak}

Berdasarkan hasil penelitian jumlah biomassa tegakan di atas permukaan tanah dari lima lokasi taman kota Pontianak jumlah cadangan karbon dari setiap lokasi menunjukkan bahwa lokasi perolehan terbanyak simpanan karbon diatas permukaan tanah yaitu pada lokasi sepanjang kiri-kanan Jalan Ahmad Yani 1 dengan total karbon tersimpan 236,71 ton $\mathrm{C} / \mathrm{Ha}$. Kemudian lokasi yang terkecil perolehan simpanan karbon terdapat dilokasiTaman Tugu Katulistiwa dengan jumlah 18,42 ton $\mathrm{C} / \mathrm{Ha}$. Hal ini dikarenakan pada lokasi Jalan Ahmad Yani 1 memiliki jumlah individu pohon yang cukup tinggi dibandingkan dari lokasi yang lain. Karena kepadatan jumlah pohon akan mempengaruhi jumlah karbon tersimpan pada pohon tersebut. Estimasi jumlah karbon dri lima lokasi tersaji pada Tabel 4.

Tabel 4. Estimasi jumlah Karbon di lima taman kota Pontianak

\begin{tabular}{cccc}
\hline Lokasi & $\begin{array}{c}\text { Luas } \\
(\mathrm{Ha})\end{array}$ & Jumlah Individu pohon & $\begin{array}{c}\text { Jumlah Carbon } \\
\text { (ton C/Ha }\end{array}$ \\
\hline Taman digulis & 3 & 259 & 21,16 \\
Taman Tugu Khatulistiwa & 0,0953 & 112 & 18,42 \\
Jl. Ahmad Yani & 1,3151 & 1600 & 236,71 \\
Jl. MT. Haryono & 0,32 & 318 & 112,1 \\
Hutan Pendopo Gubernur & 2,3 & 467 & 75,44 \\
\hline Berat total Karbon & & 2756 & 463,83 \\
\hline
\end{tabular}

\section{Pembahasan}

Berdasarkan hasil penelitian yang dilakukan tentang biomassa atas permukaan pada lima lokasi taman kota Pontianak diperoleh biomassa atas permukaan tanah dengan rincian biomassa atas permukaan tanah (abovegraund biomass) dan cadangan karbon pohon terbesar terdapat pada jalur hijau sepanjang kiri-kanan Jalan Ahmad Yani 1 sebesar 685,22 ton/ha biomassa dengan cadangan karbon sebesar 342,65 ton $\mathrm{C} / \mathrm{ha}$, sedangkan jumlah biomassa dan stok karbon terkecil terdapat dilokasi di taman Tugu Khatulistiwa dengan jumlah biomassa 35,76 ton/ha dan stok karbon 17,88 tonC/ha. Jumlah biomassa tersimpan beberapa taman di kota Pontianak berkisaran 36,85-473,42 ton/Ha Cadangan karbon yang tersimpan di lima taman kota Pontianak berkisaran antara 18,42- 
236,71 ton $\mathrm{C} / \mathrm{Ha}$ bisa dikatagorikan cukup besar dikarenakan tidak jauh berbeda dengan hasil penelitian Masripatin et.al. (2011) menyebutkan bahwa cadangan karbon pada berbagai kelas penutupan lahan di hutan alam berkisar antara 7,50 - 264,70 ton C/ha. Selain itu, dibandingkan hasil penelitian yang dilakukan oleh Indrajaya, et al. (2016) tentang biomassa atas permukaan tanah di hutan rakyat jamblang di Kabupaten Bantul dan Kabupaten Gunung Kidul adalah sebesar 137 dan 81 ton/ha, dengan karbon tersimpan dalam akar berturut-turut sebesar 22 dan 14 ton/ha. Hal ini karena jumlah individu pohon di taman dan jalur hijau di kota Pontianak lebih tinggi dibandingkan di hutan rakyat jamblang di Kabupaten. Bantul dan Kabupaten. Gunung Kidul sehingga jumlah biomassa atas permukaan tanah di beberapa taman Kota Pontianak jauh lebih besar.

Nilai biomassa dan cadangan karbon pohon ini menunjukkan bahwa lanskap hutan kota selain memiliki fungsi sebagai konservasi keanekaragaman hayati, hidrologi, dan estetika juga memiliki andil dan fungsi sebagai penyimpan biomassa dan karbon. Pohon hutan kota berperan penting tidak hanya sebagai penyimpan karbon, tetapi secara alami juga berfungsi sebagai penyerap karbon $\mathrm{CO}_{2}$ yang paling efesien. (Rayahu et al., 2007) juga menjelaskan bahwa cadangan karbon pada komunitas hutan, salah satunya dipengaruhi oleh diameter batang.

Jenis Swietenia mahagoni (Mahoni) salah satu pohon yang paling banyak ditemukan di lima lokasi penelitian biomassa di atas permukaan tanah sebesar 113,37 ton/ha dan cadngan karbon sebesar 56,68 ton/ha, dikarenakan pohon jenis ini memiliki karekteristik yang cocok ditanam di pinggir jalan yang berfungsi sebagai pohon pelindung. Selain itu, pohon kayu mahoni bisa mengurangi polusi udara sekitar $47 \%$ - $69 \%$ sehingga layak disebut pohon pelindung sekaligus filter udara dan daerah tangkapan air, sedangkan daun-daunnya, memiliki fungsi sebagai penyerap polutan-polutan di sekitarnya (Ariyantoro, 2006).

Taman Digulis Universitas Tanjungpura didominasi pohon Acacia mangium dengan jumlah biomassa rata-rata 0,11 ton/ha dan jumlah cadangan karbon di atas permukaan tanah sebesar 0,5 ton $\mathrm{C} / \mathrm{ha}$. tumbuhan ini banyak mendominasi di lokasi Taman Digulis Universitas Tanjungpura dikarenakan pohon tersebut bisa digunakan sebagai pohon penaung, ornamen, penyaring, dan penahan angin serta bisa digunakan sebagai penahan erosi. Pohon akasia juga berfungsi sebagai mengatur nitrogen udara dan menghasilkan banyak serasah, yang dapat meningkatkan aktivitas biologis tanah dan merehabilitasi sifat-sifat fisika tanah dan kimia tanah (Krisnawati et al., 2011). Oleh sebab itu pohon jenis ini banyak ditemui di taman Digulis Universitas Tanjungpura.

Jenis Roystonea regia (Palem rajah) paling banyak ditemukan jumlah individu di lokasi jalan MT Haryono dengan jumlah biomassa atas permukaan 224,23 ton/ha dan jumlah cadangan karbon atas permukaan tanah sebesar 112,1 ton $\mathrm{C} /$ ha. Jenis pohon Alstonia scholaris mendominasi di lokasi Hutan Pendopo Gubernur dengan jumlah kandungan biomasa atas permukaan tanah sebesar 21,22 ton/ha dengan besaran cadangan karbon atas permukaan tanah 10,61 ton $\mathrm{C} / \mathrm{ha}$. Sedangkan pada lokasi di Taman Tugu Khatulistiwa jenis pohon yang mendominasi adalah pohon jenis Roystonea regia (palem) dengan jumlah kandungan biomasa rata-rata 27,52 ton/ha dengan cadangan karbon atas permukaan tanah sebesar 13,76 ton $\mathrm{C} / \mathrm{ha}$. Jenis pohon Roystonea regia dari 5 lokasi penelitian paling banyak ditemukan dikarenakan menurut Haryanto dan Siswono, (1997) pohon ini memiliki tingkat adaptasi yang tinggi terhadap kondisi fisik lingkungan, serta memiliki regenerasi yang tinggi pada berbagai jenis tanah, suhu dan kelembapan udara di daerah tropis. Sehingga banyak ditemukan di beberapa lokasi penelitian.

Potensi kandungan biomassa pada tegakan pohon di 5 lokasi sampling dilakukan dengan pengukuran besaran diameter pada pohon, pada setiap lokasi pengukuran mempunyai jumlah biomassa dan cadangan karbon yang berbeda - beda sehingga memperngaruhi jumlah biomassa dan cadangan karbon yang terkandung pada pohon. Jumlah biomassa yang terkandung pada vegetasi di tanaman jalur hijau dan taman kota Pontianak ini merupakan gambaran produktifitas taman kota dan jalur hijau. Karena pada dasarnya pembentukan bagian tubuh tanaman berhubungan dengan jumlah biomassanya semakin lama umur tanaman akan semakin besar pula biomassa yang dihasilkan.

Biomassa yang dihasilkan pada setiap jenis pohon juga berbeda - beda yang akan menyebabkan perbedaan pada kualitas kayu, jumlah biomassa yang dihasilkan oleh tanaman tahunan juga lebih besar dari pada tanaman semusim karena pada tanaman tahunan pada umumnya memiliki siklus 
hidup yang panjang seperti pada vegetasi hutan, begitu juga dengan vegetasi yang ada pada tanaman jalur hijau dan taman kota Pontianak ini sehingga akumulasi biomassa juga semakin besar. Tanaman atau pohon berumur panjang yang tumbuh di hutan maupun di kebun campuran (agroforestri) merupakan tempat penyimpanan $\mathrm{C}$ yang jauh lebih besar dari pada tanaman semusim karena pada tanaman tahunan seperti di Tanaman jalur hijau dan taman di kota Pontianak ini memiliki siklus hidup yang lebih panjang sedangkan pada tanaman semusim lepasnya karbon akan lebih cepat mengingat setelah tanaman tidak berproduksi akan di ganti dengan tanaman yang baru. Oleh karena itu, hutan alami dengan keragaman jenis pepohonan berumur panjang dan seresah yang banyak merupakan gudang penyimpan $\mathrm{C}$ tertinggi (baik di atas maupun di dalam tanah). Sistem Hutan juga melepaskan $\mathrm{CO}_{2}$ ke udara lewat respirasi dan dekomposisi (pelapukan) serasah, namun pelepasannya terjadi secara bertahap, tidak sebesar bila ada pembakaran yang melepaskan $\mathrm{CO}_{2}$ sekaligus dalam jumlah yang besar. Bila hutan diubah fungsinya menjadi lahan - lahan pertanian atau perkebunan atau ladang penggembalaan maka jumlah $\mathrm{C}$ tersimpan akan merosot (Hairiah dan Rahayu, 2007).

Menurut Ratnaningsih dan Suhesti (2010) biomassa tanaman merupakan ukuran yang sering menggambarkan pertumbuhan tanaman atau menyatakan berat bahan hidup yang dihasilkan oleh tanaman. Biomassa pada setiap bagian pohon meningkat secara proporsional seiring dengan meningkatnya dimensi pohon tersebut, sehingga biomassa pada setiap bagian pohon mempunyai hubungan dengan diameter pohon (Catur dan Sidiyasa, 2001). Selain kedua faktor besaran diameter pohon tersebut, faktor lain yang mempengaruhi nilai cadangan karbon suatu tanaman adalah jumlah individu tanaman tersebut. Peningkatan jumlah karbon sejalan dengan peningkatan biomassanya, semakin tinggi jumlah biomassanya semakin tinggi pula jumlah karbon yang tersimpan. Prosentase kandungan karbon dalam bahan organik adalah $46 \%$ dari jumlah biomassanya (Hairiyah dan Rahayu, 2007). Jumlah biomassa yang tersimpan pada tegakan pohon dapat digunakan untuk mengetahui jumlah karbon yang tersimpan pada tegakan pohon, karena $46 \%$ biomassa adalah berbentuk karbon (Brown dan Lugo, 1984).

\section{UCAPAN TERIMA KASIH}

Penelitian ini merupakan penelitian dibawah payung riset Dr. Rafdinal, S.Si., M.Si dan Riza Linda, S.Si., M.Si. Penulis mengucapkan terima kasih kepada Dr. Rafdinal, S.Si., M.Si dan Riza Linda, S.Si, M.Si serta mahasiswa yang telah membantu penelitian ini yaitu Hoirul Anam dan Anita yang telah membantu pengambilan data di lapangan.

\section{DAFTAR PUSTAKA}

Azham Z. 2015. Estimasi Cadangan Karbon Pada Tutupann Lahan Hutan Sekunder, Semak dan Belukar di Kota Samarinda. Jurnal Agrifor vol 14 no 2 , hal :325-338

Adhitya W.P, Hardiyansa, dan Yani. 2013. Estimasi Kandungan Karbon Atas Permukaan Tanah Pada Pohon Dikawasan Hutan Kota Kabupaten Ketapang. Jurnal lingkunganvol 1.hal 23-32

Ariyantoro, H. 2006. Budidaya Tanaman Kehutanan. PT. Citra Aji Parama. Yogyakarta

Badan Perencanaan Pembangunan Daerah Kota Pontianak. 2003. Rencana Detail Tata Ruang Kawasan Sentra Agribisnis Kota Pontianak

Brown.S, 1997. Estimating Biomass change of tropical forest a primer FAO, Forestry paper No. 134. USA

Brown.S, dan Lugo, A.E., 1994. Biomass of tropical Forest: a new estimate based on forest volumes. Science, 223: 1290-1293

Catur, W dan K, Sidiyasa. 2001. Model pendugaan biomassa pohon mahoni (swietenia macrophylla king) di atas permukaan tanah. Penelitian Hutan dan Konversi Lahan

Hairiah, K dan S. Rahayu. 2007. Pengukuran Karbon Tersimpan di Berbagai Macam Penggunaan Lahan. World Agroforestry Centre.Bogor.

Hairiah, K., A. Ekadinata, R.R. Sari, dan S. Rahayu. 2011. Pengukuran Cadangan Karbon: dari tingkat lahan ke bentang lahan. Edisi kedua. World Agroforestry Centre, Bogor

Haryanto dan Siswono.1997. Sifat-sifat Morfologis dan Anatomi Langkap (Arenga obtusifolia). Jurnal Media Konservasi Khusus 2: 105-109

Indrajaya, Y dan Sudomo, A. 2016.Karbon tersimpan dalam biomassa hutan rakyat Jamblang di 
Kabupaten Bantul dan Gunung Kidul, Yogyakarta. Jurnal Balai Penelitian dan Pengembangan Teknologi Agroforestry, Vol 6, No.1, Th, 2016

International Centre for Research in Agroforestry. 2009. Cadangan Karbon di Kabupaten Nunukan, Kalimantan Timur

Intergovernmental Panel on Climate Change.2006. Guidelines for National Greenhouse Gas Inventories: References Manual. Paris

Ketterings QM, Coe, R, van Noordwijk, M, Ambagau, Y, dan Palm, CA. 2001. Reducinguncertainty in the use of allometric biomass equations for predicting above-ground tree biomass in mixed secondary forests. Forest Ecology and Management 120:199-209

Kashengky R, 2012. Perbandingan Karbon Tersimpan Pada Beberapa Penutupan lahan di Kabupaten Mamuju Utara Sulawesi Barat berdasarkan karakteristik fisik lahannya. Institut Pertanian Bogor

Kementrian lingkungan hidup dan kehutanan. 2015. Statistik kementrian lingkungan hidup dan kehutanan. Jakarta http://www.menlhk.go.id/semua-publikasi.html

Krisnawati, H. Kallio, M dan Kanninen, M. 2011. Acacia mangiumWilld.Ekologi, Silvikultur dan Produktivitas. CIFOR

Masripatin, N., K. Ginoga, G. Pari, WS. Dharmawan, CA. Siregar, A. Wibowo, D. Puspasari, AS.Utomo, N. Sakuntaladewi, M. Lugina,Indartik, W. Wulandari, S. Darmawan, I. Heryansah, NM. Heriyanto, HH. Siringoringo, R. Damayanti, D. Anggraeni, H. Krisnawati, R. Maryani, D. Apriyanto, dan B. Subekti. 2011. Cadangan Karbon Pada Berbagai Tipe Hutan Dan Jenis Tanaman di Indonesia.Pusat Penelitian dan Pengembangan Perubahan Iklim dan Kebijakan.Bogor

Direktorat Jenderal Penataan Ruang. Departemen Pekerjaan Umum. 2006. Ruang Terbuka Hijau Sebagai Unsur Utama Tata Ruang Kota. Jakarta

Rahayu S, Lusiana B, dan Noordwijk M. 2007. Pendugaan Cadangan Karbon di Atas Permukaan Tanah pada Berbagai Sistem Penggunaan Lahan di Kabupaten Nunukan, Kalimantan Timur. [www.worldagroforestry.org/sea/publications/fil es/book/BK0089- 05/BK0089-05-2.PDF] [21 Oktober 2008]
Ratnaningsih, A. T. dan E. Suhesti. 2010. Peran Hutan Kota dalam Meningkatkan Kualitas Lingkungan. Environmental Science 2010: 1 (4) 